\title{
DUKUNGAN BIDAN TERHADAP PEMBERIAN ASI EKSKLUSIF DI PUSKESMAS JAMBLANG KABUPATEN CIREBON TAHUN 2020
}

\section{Emah Rohemah}

Akademi Kebidanan Graha Husada Cirebon

Email: Bidanemahrohemah@gmail.com

\begin{abstract}
Exclusive breastfeeding is only giving ASI without any accompanying food or drink until the baby is 6 months old. Coverage of exclusive breastfeeding at the Jamblang Health Center in Cirebon Regency which is $46.3 \%$ has not reached the national target of $80 \%$. Midwife support is a factor influencing the success of exclusive breastfeeding. The purpose of this study was to determine the relationship between midwife support and exclusive breastfeeding in the work area of the Jamblang Health Center, Cirebon Regency. This research is a qualitative descriptive survey using a cross sectional approach. The number of respondents was 104 people. Data on exclusive midwife support and breastfeeding were obtained by questionnaire. Statistical tests to determine the relationship between variables using the chi square test. The results of data analysis obtained $p$ value of midwife support 0.038 ( $p$-value <0.05) towards exclusive breastfeeding means that there is a significant relationship between midwife support for exclusive breastfeeding.
\end{abstract}

Keywords: Exclusive Breastfeeding; Midwife Support; Cross Sectional

\begin{abstract}
Abstrak
ASI eksklusif yaitu proses pemberian ASI selama 6 bulan tanpa diberi makanan dan minuman pendamping apapun. Cakupan ASI eksklusif di Puskesmas Jamblang Kabupaten Cirebon yaitu sebesar $46,3 \%$ belum mencapai target nasional yakni $80 \%$. Faktor yang menjadi keberhasilan ASI eksklusif yaitu dukungan dari bidan. Penelitian ini bertujuan guna mengetahui antara dukungan bidan terhadap pemberian ASI eksklusif di wilayah kerja Puskesmas Jamblang, Kabupaten Cirebon. Penelitian ini adalah survei deskriptif kualitatif dengan menggunakan pendekatan cross sectional. Jumlah responden adalah 104 orang. Data tentang dukungan bidan dan menyusui eksklusif diperoleh dengan kuesioner. Uji statistik guna mengetahui hubungan antar variabel menggunakan uji chi square. Hasil analisis data menunjukan bahwa niala $p$ value dukungan bidan 0,038 ( $p$ value $<0,05)$ terhadap pemberian ASI eksklusif artinya terdapat hubungan yang signifikan antara dukungan bidan terhadap pemberian ASI eksklusif.
\end{abstract}

Kata kunci: ASI Eksklusif; Dukungan Bidan; Cross Sectional

\section{Pendahuluan}

Air Susu Ibu (ASI) merupakan cairan kehidupan terbaik yang mengandung berbagai zat dan sangat dibutuhkan oleh bayi. ASI sangat baik untuk pertumbuhan bayi 
dan sesuai kebutuhannya. Selain itu, ASI dapat meningkatkan kekebalan tubuh sehingga bisa menjadi pelindung (imun) bagi bayi dari semua jenis infeksi. (Bidan dan Dosen Kebidanan Indonesia, 2018).

Menurut World Health Organization (WHO, 2017), Air Susu Ibu (ASI) diberikan pada bayi baru lahir hingga 6 bulan tanpa makanan serta minuman lain, kecuali vitamin, obat yang dianjurkan oleh tenaga kesehatan karena alasan medis disebut ASI eksklusif.

Bayi yang tidak mendapatkan ASI eksklusif beresiko terserang diare. Pemberian susu formula juga bisa mengakibatkan resiko terserang diare hingga mengakibatkan terjadinya gizi buruk karena kandungan zat gizi dalam susu formula yang tidak cukup memenuhi kebutuhan bayi (Kemenkes, 2014).

Menurut Depkes RI, bahwa perkembangan otak anak delapan puluh persen dimulai sejak didalam kandungan hingga usia 3 tahun, dikenal dengan periode emas. Oleh karena itu pada masa ini dibutuhkan pemberian ASI eksklusif selama 6 bulan serta bisa dilanjutkan hingga anak berusia 2 tahun, karena ASI mengandung karbohidrat, protein, mineral, dan lemak sesuai dengan jumlah yang dibutuhkan bayi (Kemenkes, 2014).

Berdasarkan hasil penelitian yang dilaksanakan di di Amerika Serikat bahwa bayi yang mendapatkan ASI eksklusif 6 bulan lebih rendah mengalami ISPA (infeksi saluran pernafasan) sebesar $72 \%$, lebih rendah mengalami diabetes dengan resiko $30 \%$ dan lebih rendah mengalami otitis media dengan resiko 50\%. Selain itu, ASI juga dapat menurunkan resiko SIDS (sudden infant death syndrome) sebesar 36\% (American Academy of Pediatrics, 2012).

Mengingat banyaknya manfaat yang dapat diperoleh dengan pemberian ASI eksklusif kepada bayi selama 6 bulan maka badan kesehatan dunia United Nation Children Fund (UNICEF) dan World Health Organization (WHO) merekomendasikan agar bayi yang lahir hanya mendapatkan ASI dari ibunya selama 6 bulan.

Begitupun Indonesia, Keputusan Menteri Kesehatan Nomor 450/MENKES/SK/IV/2017 sebagai peraturan tentang pentingnya ASI eksklusif bagi bayi dan Peraturan Pemerintah (PP) Nomor 33 tahun 2012.

Berdasarkan data World Health Organization (WHO), bahwa hanya 44\% dari bayi baru lahir di dunia yang mendapat ASI dalam waktu satu jam pertama sejak lahir, masih sedikit juga bayi di bawah usia 6 bulan menyusu secara eksklusif. Cakupan pemberian ASI eksklusif di Asia Selatan 47\%, Amerika Latin dan Karibia 32\%, Asia Timur 30\%, Afrika Tengah 25\%, dan Negara berkembang 46\%. Secara keseluruhan, kurang dari $40 \%$ anak di bawah usia 6 bulan di beri ASI eksklusif (WHO, 2015)

Hal tersebut belum sesuai dengan target WHO yaitu meningkatkan pemberian ASI eksklusif dalam 6 bulan pertama sampai paling sedikit 50\%. Ini merupakan target ke lim

a WHO di tahun 2025 (WHO, 2014)

Menurut data pemantauan status gizi di Indonesia pada tahun 2017 menunjukan cakupan pemberian ASI eksklusif selama 6 bulan pertama oleh ibu kepada bayinya masih sangat rendah yakni $35,7 \%$. Artinya ada $65 \%$ bayi yang tidak diberikan ASI 
secara eksklusif selama 6 bulan saat lahir. Angka ini cukup jauh dari target cakupan ASI eksklusif pada 2019 yang ditetapkan oleh WHO ataupun Kementrian Kesehatan yaitu 80\% (Kemenkes RI, 2017)

Berdasarkan Profil Kesehatan Provinsi Jawa Barat tahun 2017 cakupan ASI eksklusif di Jawa Barat sebesar 53,0\%. Sedangkan untuk Kab. Cirebon presentase bayi yang mendapatkan ASI eksklusif terhadap bayi umur 0-6 bulan sebesar 32,79\%. Angka pemberian ASI eksklusif tersebut masih rendah karena target cakupan pemberian ASI eksklusif pada bayi 0-6 bulan adalah 80\% (Kemenkes, 2015).

Berdasarkan hasil studi pendahuluan yang dilakukan di Puskesmas Jamblang diperoleh bahwa cakupan pemberian ASI eksklusif Puskesmas Jamblang pada tahun 2019 sudah mencapai target pemberian ASI eksklusif yaitu 40\%, namun belum mencapai target yang ditetapkan WHO dan Kemenkes sebesar 80\%, dimana cakupan pemberian ASI eksklusif Puskesmas Jamblang pada tahun 2019 sebesar 46,3\%.

Berdasarkan hasil wawancara yang dilakukan peneliti terhadap pegawai bagian Koordinator Gizi (Nutrisionis) Puskesmas Jamblang Kabupaten Cirebon diketahui bahwa cakupan pemberian ASI eksklusif tahun 2019 mengalami penurunan dari tahun sebelumnya sebesar 7,9\%, dimana pada tahun 2018 sebesar 54,2\% dan tahun 2019 sebesar 46,3\%. Beliau juga menyebutkan bahwamasih sedikit ibu-ibu yang menyusui secara eksklusif. Anggapan ibu-ibu selama ini adalah makanan pendamping ASI lebih bisa membuat bayi lebih sehat, tidak rewel dan juga faktor kebudayaan dan tradisi yang menyebabkan rendahnya pemberian ASI eksklusif. Ibu-ibu juga meyakini bahwa makanan tersebut dapat membuat bayi cepat kenyang, cepat gemuk, dan tidak mudah sakit.

Berbagai faktor yang mempengaruhi keberhasilan ASI eksklusif seperti faktor pengetahuan ibu, faktor psikologis, faktor fisik ibu, faktor sosial budaya, faktor dukungan tenaga kesehatan, serta faktor dukungan keluarga. Faktor dukungan tenaga kesehatan khususnya bidan sangat berpengaruh terhadap keberhasilan ASI eksklusif. Hal tersebut sesuai Peraturan Pemerintah (PP) Nomor 33 tahun 2012, yang menyebutkan bahwa Bidan bertanggung jawab untuk memberikan pendidikan terkait ASI eksklusif serta memberikan support pada ibu menyusui yang dimulai sejak proses kehamilan, saat pertama kali ibu menyusui hingga dengan selama ibu menyusui. Dukungan yang diberikan Bidan juga dapat meningkatkan rasa kepercayaan diri pada ibu untuk terus memberikan ASI eksklusif pada bayinya (Alianmoghaddam, Phibbs, \& Benn, 2017).

\section{Metode Penelitian}

Penelitian ini adalah penelitian survey deskritif kualitatif dengan menggunakan pendekatan cross sectional dimana pengamatan terhadap variabel bebas dan terikat dilakukan dalam waktu yang bersamaan.

Penelitian ini dilakukan di wilayah kerja Puskesmas Jamblang Kab. Cirebon dan dilaksanakan pada tanggal 10-12 bulan Februari tahun 2020. 
Populasi merupakan keseluruhan subjek penelitian atau objek yang diteliti (Notoatmodjo, 2015). Pada penelitian ini populasinya ialah Ibu yang mempunyai bayi berusia 7 - 24 bulan di wilayah kerja Puskesmas Jamblang sebanyak 1.036 orang. Kriteria inklusi dari penelitian ini adalah Ibu yang menetap di wilayah kerja Puskesmas Jamblang, bersedia menjadi responden, dan dengan kondisi sehat baik fisik ataupun mental, Bayi dalam keadaan sehat. Kriteria eksklusi pada penelitian ini adalah Ibu dengan keadaan patologis yang tidak dapat menyusui bayinya seperti kanker payudara, HIV, Ibu yang mempunyai bayi dengan keadaan patologis misalnya gangguan kongenital, gangguan pencernaan.

Pengambilan sampel pada penelitian ini, karena jumlah populasi lebih dari 100, maka jumlah sampel diambil $10 \%$ dari jumlah populasi. Dimana didapatkan jumlah sampel pada penelitian ini sebanyak 104 responden.

Variabel dalam penelitian ini mencakup variabel terikat yaitu dukungan bidan dan variabel bebasnya pemberian ASI eksklusif.

Jenis data dalam penelitian ini menggunakan data primer, yaitu ibu menyusui yang mempunyai bayi usia 7-24 bulan di wilayah kerja Puskesmas Jamblang.

Pengambilan data responden dilakukan dengan cara menyebar kuesioner langsung ke 104 Ibu yang memiliki bayi usia 7-24 bulan di wilayah kerja Puskesmas Jamblang mengenai dukungan bidan dan pemberian ASI eksklusif.

\section{Hasil dan Pembahasan}

\section{A. Analisis univariat}

\section{Dukungan bidan}

Tabel 1 Distribusi Frekuensi Dukungan Bidan terhadap Pemberian ASI Eksklusif di Wilayah Kerja Puskesmas Jamblang Kabupaten Cirebon

Tahun 2020

\begin{tabular}{llll}
\hline No. & Dukungan Bidan & F & \% \\
\hline 1 & Mendukung & 57 & 54,8 \\
\hline 2 & Kurang Mendukung & 47 & 45,2 \\
\hline & Total & 104 & 100 \\
\hline
\end{tabular}

Berdasarkan tabel 1 diatas mengenai distribusi frekuensi dukungan bidan terhadap pemberian ASI eksklusif, bahwa jumlah responden yang mendapat dukungan bidan terhadap pemberian ASI eksklusif sebesar 54,8\% (57 responden) lebih banyak dibandingkan dengan responden yang kurang mendapat dukungan bidan terhadap pemberian ASI eksklusif yaitu 45,2\% (47 responden).

Hasil penelitian ini sesuai dengan teori (Alianmoghaddam et al., 2017), bahwa faktor tenaga kesehatan khususnya bidan sangat berpengaruh terhadap keberhasilan ASI eksklusif. Dimana Bidan bertanggung jawab dalam memberikan pendidikan terkait ASI eksklusif serta memberikan dukungan terhadap ibu menyusui yang dimulai saat proses kehamilan, saat pertama kali ibu menyusui hingga sampai selama ibu menyusui. Selain itu dukungan bidan 
juga bisa memberikan kepercayaan diri terhadap ibu untuk terus memberikan ASI eksklusif terhadap bayinya (Alianmoghaddam et al., 2017).

Menurut (Presiden Republik Indonesia, 2014), bidan wajib memberikan informasi dan edukasi ASI eksklusif kepada ibu. Dukungan bidan dalam mensosialisasikan ASI eksklusif dapat dimulai sejak pemeriksaan kehamilan sampai dengan periode pemberian ASI eksklusif. Informasi dan edukasi yang diberikan meliputi keuntungan dan keunggulan ASI, gizi ibu dan persiapan serta mempertahankan menyusui.

Puskesmas Jamblang Kabupaten Cirebon telah melaksanakan berbagai program ASI eksklusif diantaranya melakukan penyuluhan mengenai ASI eksklusif saat Posyandu dan saat pemeriksaan kehamilan. Puskesmas Jamblang juga menempelkan poster mengenai ASI eksklusif di beberapa ruangan diantaranya ruangan untuk pemeriksaan kehamilan, ruangan gizi maupun ruang tunggu pasien. Selain itu juga disediakan ruangan tempat menyusui di Puskesmas.

Jadi, pada dasarnya semua bidan mendukung dalam pemberian ASI Eksklusif. Dimana dalam hal ini peran bidan sebagai pendidik dan sebagai pelaksana telah dilakukan untuk mendukung ibu menyusui. Sebagai pendidik, Bidan memberikan pendidikan dan penyuluhan kesehatan kepada individu dan keluarga, kelompok dan masyarakat. Meskipun pada kenyataannya fenomena yang terjadi di lapangan pada saat bidan memberikan penyuluhan terkadang ibu tidak fokus terhadap penyuluhan. Karena biasanya fokus ibu teralihkan pada bayinya, yang terkadang rewel atau kurang nyaman pada keramaian.

\section{Pemberian ASI eksklusif}

Tabel 2 Distribusi Frekuensi
Pemberian ASI Eksklusif di Wilayah Kerja Puskesmas Jamblang
\begin{tabular}{cccc} 
& Kabupaten Cirebon Tahun 2020 \\
\hline No. & Pemberian ASI Eksklusif & F & \% \\
\hline 1 & ASI Eksklusif & 47 & 45,2 \\
\hline 2 & Tidak ASI Eksklusif & 57 & 54,8 \\
\hline & Total & 104 & 100 \\
\hline
\end{tabular}

Berdasarkan tabel 2 diatas mengenai distribusi frekuensi pemberian ASI eksklusif, bahwa jumlah responden yang tidak memberikan ASI eksklusif sebesar 54,8\% (57 responden) lebih banyak dibandingkan dengan responden yang memberikan ASI eksklusif yaitu 45,2\% (47 responden).

Meskipun jumlah responden yang tidak memberikan ASI eksklusif lebih banyak dibandingkan dengan responden yang memberikan ASI eksklusif tapi tidak mempengaruhi aktifitas penelitian ini. Adapun faktor yang mempengaruhi pemberian ASI eksklusif salah satunya adalah faktor dukungan tenaga kesehatan khususnya bidan. Bidan merupakan petugas kesehatan yang 
paling dekat dengan wanita. Dukungan bidan akan menentukan perilaku pemberian ASI eksklusif (Ariwati, Rosyidi, \& Pranowowati, 2014).

Berdasarkan hasil penelitian dapat diketahui bahwa sebagian besar Ibu yang kurang mendapatkan dukungan dari bidan untuk memberikan ASI eksklusif yaitu sebanyak 45,2\% (47 responden).

Sesuai dengan teori (Astutik, 2014), yang menyatakan bahwa kurangnya dukungan tenaga kesehatan khususnya bidan menyebabkan ibu kurang motivasi untuk memberikan ASI eksklusif. Untuk itu, Bidan berperan dalam keberhasilan ASI eksklusif mulai dari edukasi selama kehamilan hingga selama proses ibu menyusui.

\section{B. Analisis bivariat}

Setelah dilakukan analisis univariat, dilakukan analisis bivariat, untuk melihat hubungan antara variabel bebas (dukungan bidan) dan variabel terikat (pemberian asi eksklusif) dengan menggunakan uji Chi-square dengan tingkat signifikasi 0,05. Adapun hasil penelitian diperoleh data sebagai berikut:

Tabel 3 Hubungan antara Dukungan Bidan terhadap Pemberian ASI Eksklusif di Wilayah Kerja Puskesmas Jamblang Kabupaten Cirebon Tahun 2020

\begin{tabular}{|c|c|c|c|c|c|c|c|}
\hline \multirow{3}{*}{ Dukungan Bidan } & \multicolumn{4}{|c|}{ Pemberian ASI Eksklusif } & \multicolumn{2}{|c|}{ Total } & \multirow{3}{*}{ p-value } \\
\hline & \multicolumn{2}{|c|}{$\begin{array}{c}\text { ASI } \\
\text { Eksklusif }\end{array}$} & \multicolumn{2}{|c|}{$\begin{array}{l}\text { Tidak ASI } \\
\text { Eksklusif }\end{array}$} & \multirow[t]{2}{*}{$\mathbf{F}$} & \multirow[t]{2}{*}{$\%$} & \\
\hline & $\mathbf{F}$ & $\%$ & $\mathbf{F}$ & $\%$ & & & \\
\hline Mendukung & 31 & 29,8 & 26 & 25,0 & 57 & 54,8 & \multirow[b]{2}{*}{0,038} \\
\hline $\begin{array}{c}\text { Kurang } \\
\text { Mendukung }\end{array}$ & 16 & 15,4 & 31 & 29,8 & 47 & 45,2 & \\
\hline Total & 47 & 45,2 & 57 & 54,8 & 104 & 100 & \\
\hline
\end{tabular}

Berdasarkan tabel 3 di atas didapatkan, hasil analisis hubungan antara dukungan Bidan terhadap pemberian ASI eksklusif di Wilayah Kerja Puskesmas Jamblang Kabupaten Cirebon tahun 2020 dengan metode korelasi Chi square, diperoleh bahwa Ibu yang mendapat dukungan dan memberikan ASI eksklusif yaitu sebanyak 29,8\% (31 responden), persentase tersebut lebih tinggi jika dibandingkan dengan Ibu yang mendapat dukungan dan memberikan ASI eksklusif yaitu sebanyak 25,0\% (26 responden). Sedangkan persentase Ibu yang kurang mendapakan dukungan dan memberikan ASI eksklusif yaitu 15,4\% (16 responden) lebih rendah jika dibandingkan dengan Ibu yang kurang mendapatkan dukungan dan tidak memberikan ASI eksklusif yaitu sebanyak 29,8\% (31 responden).

Berdasarkan hasil uji statistik dengan menggunakan chi square didapatkan hasil $p$ value $=0,038$. Nilai $p$ value $<0,05$ maka Ho ditolak, yang berarti bahwa ada hubungan antara dukungan bidan terhadap pemberian ASI eksklusif.

Hal ini menunjukkan bahwa keberhasilan pemberian ASI eksklusif juga dipengaruhi oleh dukungan tenaga kesehatan khususnya bidan. Ibu yang mendapatkan dukungan baik dari Bidan akan menjadi lebih percaya diri dalam 
memberikan ASI eksklusif, namun dukungan baik dari Bidan juga tidak sepenuhnya dapat mempengaruhi ibu dalam pemberian ASI eksklusif. Hal ini disebabkan keterampilan konseling yang dimiliki oleh bidan baik dalam menyampaikan informasi dan edukasi bagi ibu mengenai ASI eksklusif.

Keterampilan (skill) adalah salah satu faktor untuk mencapai kompetensi bidan dalam memberikan dukungan. Keterampilan konseling yang baik sangat penting dimiliki oleh seorang Bidan karena hal tersebut dapat menumbuhkan rasa percaya masyarakat kepada seorang Bidan. Selain itu bidan yang terampil jugaakan merasa memiliki kemampuan yang baik untuk memberi dukungan (Siti, 2012).

Hasil penelitian ini juga selaras dengan penelitian (Aisyaroh \& Unissula, 2016) yang menyatakan bahwa terdapat hubungan antara dukungan bidan dalam pemberian ASI eksklusif dengan $p$ value $<0,05$ sebesar 0,037. Hasil tersebut menunjukkan bahwa dukungan bidan merupakan upaya yang dilakukan oleh bidan untuk membentuk perilaku ibu untuk memberikan ASI eksklusif.

Sesuai dengan teori dari (Notoatmodjo, 2010), bahwa perilaku dipengaruhi oleh dukungan tenaga kesehatan karena dengan diberikan dukungan oleh tenaga kesehatan sebagai kelompok referensi, seseorang akan dapat menentukan perilakau sehat.

Selain itu, hasil penelitian ini juga selaras dengan teori (Proverawati \& Rahmawati, 2010) yang menyatakan bahwa Ibu menyusui membutuhkan lebih banyak dukungan dan pertolongan baik ketika mereka memulai maupun melanjutkan menyusui. Sebagai langkah awal mereka membutuhkan bantuan sejak kehamilan dan setelah persalinan. Ibu menyusui membutuhkan dukungan pemberian ASI secara eksklusif baik dari bidan, keluarga juga lingkungan sekitarnya.

Namun, dukungan bidan tidak sepenuhnya dapat mempengaruhi seorang Ibu dalam pemberian ASI eksklusif. Meskipun telah mendapat dukungan bidan dalam pemberian ASI eksklusif terdapat sebagian kecil respondenyang tidak memberikan ASI eksklusifyaitu sebesar 25,0\% (26 responden). Hal ini disebabkan karena ada beberapa faktor yang mempengaruhi seperti ASI yang tidak keluar pada waktu melahirkan sehingga bayi segera diberi susu formula. Kemudian faktor lainnya yaitu Ibu merasa ASI yang diberikan tidak cukup untuk bayinya sehingga memberikan makanan tambahan selain ASI sebelum bayi usia 3 bulan. Selain itu penyebab gagalnya pemberian ASI eksklusif yaitu budaya memberikan madu, air, dan pisang lumat yang dianggap baik untuk bayi.

\section{Kesimpulan}

Berdasarkan hasil penelitian yang dilakukan oleh peneliti dapat ditarik kesimpulan sebagai berikut:

Persentase Ibu yang mendapatkan dukungan bidan untuk pemberian ASI eksklusif di wilayah kerja Puskesmas Jamblang Kabupaten Cirebon yaitu 54,8\% (57 responden). Persentase Ibu yang tidak memberikan ASI eksklusif yaitu 54,8\% (57 responden). 
Angka tersebut masih belum mencapai target nasional cakupan ASI eksklusif yaitu $80 \%$.

Berdasarkan uji statistik dengan menggunakan uji chi square nilai $p$ value $=$ 0,038 $(<0,05)$ yang berarti $\mathrm{H}_{\mathrm{o}}$ ditolak dan $\mathrm{H}_{\mathrm{a}}$ diterima. Dapat disimpulkan bahwa ada hubungan antara dukungan bidan terhadap pemberian ASI eksklusif di wilayah kerja Puskesmas Jamblang Kabupaten Cirebon. Dengan nilai koefisien kontingensi positif sebesar 0,199, yang berarti tingkat keeratan hubungannya adalah sangat rendah. 


\section{BIBLIOGRAFI}

Aisyaroh, Noveri, \& Unissula, Staff Pengajar D. III Kebidanan. (2016). Dukungan Bidan dalam Pemberian ASI Eksklusif di Desa Sumbersari Kecamatan Ngampel Kabupaten Kendal.

Alianmoghaddam, Narges, Phibbs, Suzanne, \& Benn, Cheryl. (2017). Resistance to breastfeeding: A Foucauldian analysis of breastfeeding support from health professionals. Women and Birth, 30(6), e281-e291.

Ariwati, Valentina Dili, Rosyidi, M. Imron, \& Pranowowati, Puji. (2014). Hubungan Dukungan Bidan tentang Pemberian ASI Eksklusif dengan Perilaku Pemberian ASI Eksklusif di Wilayah Kerja Puskesmas Ambarawa Kabupaten Semarang. STIKES Ngudi Waluyo Ungaran.

Astutik, Reni Yuli. (2014). Payudara dan laktasi. Jakarta: Salemba Medika, 47-50.

Indonesia, Bidan dan Dosen Kebidanan. (2018). Kebidanan: Teori dan Asuhan Volume 2. Jakarta: EGC.

Indonesia, Presiden Republik. (2014). Peraturan Pemerintah Republik Indonesia nomor 33 tahun 2012 tentang pemberian air susu ibu eksklusif.

Kemenkes, R. I. (2014). Manajemen laktasi: buku panduan bagi bidan dan petugas kesehataan di puskesmas. Jakarta: Dirjen Bina Kesehatan Masyarakat.

Kemenkes, R. I. (2015). Profil kesehatan Indonesia tahun 2014. Jakarta: Kemenkes RI.

Notoatmodjo, Soekidjo. (2015). Metodologi penelitian kesehatan. Jakarta: rineka cipta.

Organization, World Health. (2014). Global nutrition targets 2025: Stunting policy brief. World Health Organization.

Organization, World Health. (2015). World health statistics 2015. World Health Organization.

Pediatrics, American Academy of. (2012). Breastfeeding and The Use of Human Milk. Pediatrics, 3(129), 827-841.

Proverawati, Atikah, \& Rahmawati, Eni. (2010). Kapita selekta ASI dan menyusui. Yogyakarta: Nuha Medika, 9, 13-17.

RI, Kementerian Kesehatan. (2017). Profil Kesehatan Indonesia Tahun 2016.

Siti, Maryam. (2012). Peran Bidan dalam Menyukseskan MDGS. Jakarta. Salemba. 